\title{
Chronically ill patients' expectations of therapeutic education and their health locus of control
}

\section{BACKGROUND}

Beliefs as cognitive components of personality indicate what we consider as true or false and help us to answer questions concerning others, the world surrounding us and situations that we encounter. Beliefs about the health locus of control and their relations with expectations pertaining to therapeutic education seem to be of vital importance in the case of occurrence of a chronic illness.

The aim of this paper is to verify whether expectations concerning therapeutic education in chronically ill patients demonstrate a relation with beliefs about the health locus of control and whether they vary according to gender, age and health, and to present the results of research that applies the Polish OE-15 scale for the evaluation of therapeutic education expectations depending on the health condition.

\section{PARTICIPANTS AND PROCEDURE}

Two hundred and ninety-one persons were examined, including 180 patients and 111 healthy controls (the control group), 187 women and 104 men. The average age of subjects was $45.71(S D=13.51)$ years, ranging from 21 to 80 years.

The OE-15 Therapeutic Education Expectations Scale and the Multidimensional Health Locus of Control Scale in versions relevant for patients and healthy controls as well as demographics were used.

\section{RESULTS}

Age, gender and beliefs about the health locus of control are related to expectations of therapeutic education.

\section{CONCLUSIONS}

When providing therapeutic education for chronically ill patients, one should assess their expectations and pay attention to patients' beliefs about the health locus of control.

\section{KEY WORDS}

expectations of therapeutic education; beliefs about the health locus of control; chronically ill patients

ORganization - 1: Institute of Psychology, Casimir the Great University, Bydgoszcz, Poland · 2: Department of Health

Promotion Collegium Medicum, Nicolaus Copernicus University in Torun, Poland

aUthors' Contributions - A: Study design - B: Data collection - C: Statistical analysis - D: Data interpretation .

E: Manuscript preparation · F: Literature search G: Funds collection

CORRESPONDING AUTHOR - Prof. Małgorzata Anna Basińska, Institute of Psychology, Casimir the Great University,

1 Staffa Str., 85-867 Bydgoszcz, Poland, e-mail: mbasinska@ukw.edu.pl

to Cite this ARTICLE - Basińska, M. A., \& Andruszkiewicz, A. (2016). Chronically ill patients' expectations of therapeutic

education and their health locus of control. Health Psychology Report, 4(2), 91-102. doi: 10.5114/hpr.2016.55875

RECEIVED 04.01.2015 · REVIEWED 30.01.2015 · ACCEPTED 28.06.2015 · PUBLISHED 31.12.2015 


\section{BACKGROUND}

In the biopsychosocial model efforts are made that aim at including patients in a broadly understood treatment process and that are significant for patients' therapy and care, and also in education (e.g. Kubica, 2012). Education is effective when it responds to the expectations of patients (Basińska, 2005; Astin, Closs, McLenachan, Hunter, \& Priestley, 2009; Abramczyk 2010). This paper presents the results of research on relations between expectations of therapeutic education and health, and beliefs about the health locus of control.

\section{PATIENTS’ EXPECTATIONS OF EDUCATION}

Patient education is a vital element of modern healthcare. Health education, patient education and therapeutic education are terms that are quite frequently interchangeably used in the subject literature. Therefore it seems vital to systematise and specify these concepts at this early stage of our deliberations. Health education is defined as a process in which people learn to take care of their own health and of the health of other persons in the community they live in. This process encompasses several stages, from realising the existence of a health problem to taking decisions and undertaking activities to change health-related behaviours. This definition stresses relations between human health and the physical and social environment (Williams, 1998).

Therapeutic education is described by the World Health Organization as follows: "Therapeutic patient education should enable patients to acquire and maintain abilities that allow them to optimally manage their lives with their disease. It is therefore a continuous process, integrated in health care. It is patient-centred; it includes organized awareness, information, self-care learning and psychosocial support regarding the disease, prescribed treatment, care, hospital and other health care settings, organizational information, and behaviour related to health and illness. It is designed to help patients and their families understand the disease and the treatment, cooperate with health care providers, live healthily, and maintain or improve their quality of life" (WHO Copenhagen, 1998, p. 17). In this perspective education is a complex and multidimensional process.

Patient education is a planned activity, developed for the improvement of health-related behaviours of patients and their health (Lorgin, 2001). Patient education can be divided into two categories: clinical patient education (or clinical learning and teaching) and health education. Clinical patient education is a planned, systematic, sequential and logical process of learning and teaching patients and clients in all clinical situations (related to the disease). It is a process of constant learning and teaching, in which healthcare personnel as well as patients or clients (and/or their families) participate. Health education is also a process of learning and teaching, similarly to clinical education, but it focuses mainly on health maintenance and prevention. Health education is targeted at individuals, groups and communities (Dreeben-Irimia, 2009; Andruszkiewicz \& Basińska, in press).

In 1999 during a meeting in Paris, the aim of which was the presentation and development of procedures related to patient education, representatives of medical environments agreed on a working definition and assumed that patient education concerns all educational activities directed at patients, including aspects of therapeutic education, health education and clinical health promotion (Deccache \& Aujoulat, 2001; Visser, Deccache, \& Bensing, 2001).

It seems essential and accurate to use the concept of therapeutic education in reference to the education of chronically ill patients so as to avoid multiple terms and to consider the aforementioned definitions. First of all, this approach reflects the whole spectrum of issues that should be taken into account in the education process; it also draws our attention to the specificity of educating patients. Education defined in this way goes beyond simple information and explanation, and it assumes active involvement of the patient and their environment in the treatment process.

In medical literature the importance of the patient-centred approach is strongly underlined; characteristic features of this approach include the need to consider patients' preferences, values and needs concerning information and education. Medical personnel should take into account patients' expectations and encourage them to take responsibility for their own health (Tongue, Epps, \& Forese, 2005; West, Barron, \& Reeves, 2005).

Research on patients' expectations is conducted mostly in the context of assessment and quality of medical services delivered. It would be recommended to view them as needs, wishes or requests expressed prior to a medical appointment (Williams, Weinman, Dale, \& Newman, 1995), as the knowledge of patients' expectations allows one to undertake more accurate and effective actions (Rao, Weinberger, \& Kroenke, 2000; McKinley \& Roberts, 2001). The effective management of the disease requires from the patient such skills as recognising symptoms of the disease and knowing how to react appropriately if they occur, adequate drug taking, proceeding in emergencies, selecting a diet and types of physical activity, effective relations with healthcare staff, using local community resources, adapting to working environments or coping with psychological problems related to the disease (McKinley \& Roberts, 2001; Halsted, 2004). Research demonstrated that many patients do not follow instructions required within the treatment process if these instructions do not consider the 
needs, expectations and existing experiences of the patient (Levin-Zamair \& Peterburg, 2001).

Due to education, strong points of the patient and their own resources in coping with the disease are enhanced, which can prevent unfavourable behaviours during treatment and improve patients' wellbeing in the long run. There is an underlying assumption for such effects which claims that the more patients know about their disease, the better they can cope with it (Patient Education - a Health Technology Assessment, 2009).

In our current understanding it is the patient who is mostly responsible for the treatment of chronic diseases as a person who can really affect the course of the disease, and members of the treatment team should perform the role of consultants rather than mentors and show how to proceed. This active participation of the patient in treatment therapy translates into positive treatment results (Sawicki et al., 1995; Briggs, Kirchhoff, Hammes, Song, \& Colvin, 2004; Rachmani, Slavachevski, Berla, Frommer-Shapira, \& Ravid, 2005; Gambling \& Long, 2010; Hoglund, Winblad, Arnetz, \& Arnetz, 2010; Lagger, Pataky, \& Golay, 2010).

\section{BELIEFS ABOUT THE HEALTH LOCUS OF CONTROL}

Following the cognitive approach towards the way humans function, people do not generally react to external stimuli directly, but rather they react to their cognitive representation. In order to understand human behaviours, we should focus not only on these behaviours alone, but also on related cognitive processes (Bishop, 2000).

Julian B. Rotter (1990), the author of the concept of the locus of control, said that the fact of whether a given individual is going to undertake a given action is the function of expectation that this action is going to yield a specific result, and of the value of this result for the individual. Expectations are affected by the perceived interdependence between behaviour and result. Rotter assumed in his theory that the perception of this interdependence is constructed on the basis of observing one's own behaviours and the behaviour of other people. While seeking ways to arrange them, humans search for regularities that govern the sequence. The individual's perception of the result as being the effect of luck, chance, destiny, as something controlled by others, denotes the external locus of control. If the individual perceives an event as it is controlled by their own actions or own lasting properties, then it is characterised by the internal locus of control. Beliefs about the external or internal locus of control can be treated as generalised expectations resulting from personality predispositions of the individual.

Referring the phenomenon of the locus of control (LOC) to health is related to the image of one's dis- ease and human behaviour in illness. The concept of the health locus of control developed by the Wallstons (Wallston, Wallston, \& DeVellis, 1978; Wallston \& Wallston, 1982) is based on socio-cognitive theories and the holistic approach towards health and disease. These beliefs are generalisable, are relatively stable and address determinants of the results of our actions. Persons with an internal LOC are more responsible for their health as well as for the process of treatment and rehabilitation. In order to maintain a good general mental and physical state, they are more prone to undertaking efforts than persons with an external LOC. Yet this occurs only when an individual places health high in their hierarchy of values. If an individual does not perceive health as valuable, they will not assume external responsibility for it (Wallston, Wallston, Smith, \& Dobbins, 1987).

Generally, an external health locus of control is associated with being chronically ill, with such negative emotions as depression, hostility, anxiety, and with physical symptoms. An external LOC may affect somatic health through its relations with mental state (Vandervoort, Luis, \& Hamilton, 1997). Individuals with an external locus of control more frequently apply passive avoidance ways of coping and negative affect (Masters \& Wallston, 2005). These individuals are not focused on expanding the knowledge on their own health (Beier \& Ackerman, 2003).

It can be claimed that the locus of control is related to behaviour in illness. It is particularly connected to seeking information, taking medicines, seeing doctors regularly, observing a dietary regime or quitting smoking (after Wallston \& Wallston, 1978), and to undertaking health-related behaviours (Basińska, Mackowska, \& Listwan, 2011). Because the role of beliefs about health control is so important, it seemed reasonable to check its links with the expectations of therapeutic education.

\section{RESEARCH OBJECTIVE}

Because of the exploratory character of the research, we did not hypothesize. This paper aims at the realisation of two main objectives and one additional objective:

- presenting the results of research that applies the Polish OE-15 scale for the evaluation of therapeutic education expectations depending on the health condition (using appropriate tests of significance of differences);

- verifying whether patients' expectations differ according to their gender and age and whether they demonstrate any relations with their beliefs about the health locus of control (using appropriate tests of significance of differences, correlation and cluster analysis).

An additional aim was to describe the expectations of the respondents as to who should be in charge of
Chronically ill patients' expectations of therapeutic education 
the education of patients and in what form, both during the stay in the hospital and after his discharge.

\section{PARTICIPANTS AND PROCEDURE}

\section{PARTICIPANTS}

In total, 291 persons were included in the research, including $180(62.00 \%)$ patients and $111(38.00 \%)$ healthy controls, 187 (64.00\%) women and $104(36.00 \%)$ men.
Małgorzata Anna Basińska, Anna Andruszkiewicz However, due to deficiencies in completing the studies include the results of 283 people. The subjects were recruited from among volunteers to participate in the study. Healthy controls were a comparison group. The mean age of the subjects was $45.71(S D=13.51)$ years, ranging between 21 and 80 years. The patient group was significantly older $(M=51.25, S D=13.29)$ than the group of healthy controls $(M=36.41, S D=7.40, z=9.27, p<.001)$. Women $(M=45.92, S D=13.96)$ and men $(M=45.46$, $S D=12.72)$ were of similar age $(t=0.28, p=.781)$.

Table 1

Number of subjects according to demographic variables

\begin{tabular}{|c|c|c|}
\hline Variables analysed & $f$ & $\%$ \\
\hline \multicolumn{3}{|l|}{ Education } \\
\hline primary & 17 & 6.00 \\
\hline vocational & 47 & 16.61 \\
\hline secondary & 118 & 41.70 \\
\hline university & 101 & 35.69 \\
\hline no response & 8 & 2.83 \\
\hline \multicolumn{3}{|l|}{ Place of residence } \\
\hline rural areas & 64 & 23.02 \\
\hline $\begin{array}{l}\text { town with population below } \\
100,000\end{array}$ & 99 & 35.61 \\
\hline $\begin{array}{l}\text { town with population above } \\
100,000\end{array}$ & 115 & 41.37 \\
\hline no response & 13 & 4.68 \\
\hline \multicolumn{3}{|l|}{ Type of employment } \\
\hline professionally active & 184 & 64.79 \\
\hline disability pension & 39 & 13.73 \\
\hline retirement pension & 46 & 16.20 \\
\hline unemployed & 15 & 5.28 \\
\hline \multicolumn{3}{|l|}{ Living } \\
\hline with family & 252 & 89.00 \\
\hline single & 32 & 11.00 \\
\hline no response & 7 & 2.46 \\
\hline
\end{tabular}

The research subjects most frequently had secondary or university education. The lowest number of them had primary or vocational education. The highest number of subjects lived in towns with a population exceeding 100,000 inhabitants, and the lowest number lived in rural areas. The highest number of subjects were professionally active, and the lowest number were unemployed. The majority of the subjects lived with their families (Table 1).

\section{HEALTH OF SUBJECTS}

Most of the subjects were patients of specialist healthcare centres $(n=129,84.00 \%)$. Only 24 persons $(16.00 \%)$ said that they did not use the centres; others did not respond to this question. The average disease duration was 9.97 years $(S D=7.76)$, ranging between 1 and 50 years. The largest number of subjects were suffering from cardiovascular, endocrine and metabolic diseases (Table 2). Most subjects ( $n=142,79.00 \%)$ claimed co-morbidity. Only a few subjects said that they were suffering only from one major disease.

Most subjects stated ( $n=122,82.43 \%)$ that they were regularly and permanently taking various medicines. Others took medicines periodically $(n=18$, $12.16 \%$ ) or did not take them.

The subjects on the scale - where 1 denoted very bad health and 10 ideal health - evaluated their health most frequently as average ( 5 points, $n=32$, $22.70 \%$ ) or good (7 points, $n=34,24.11 \%$ ), with $M=5.79(S D=1.59)$, ranging from 2 to 10 points.

\section{METHODS}

Three research methods were applied: the MHLC scale in A and B forms for the healthy controls and

Table 2

Number of subjects according to type of disease

\begin{tabular}{lcr}
\hline Diseases & \multicolumn{1}{c}{$f$} & \multicolumn{1}{c}{$\%$} \\
\hline 1 - cardiovascular diseases & 61 & 33.89 \\
2 - respiratory diseases & 15 & 8.33 \\
3 - locomotor diseases & 15 & 8.33 \\
$\begin{array}{l}\text { - endocrine and metabolic } \\
\text { diseases }\end{array}$ & 39 & 21.67 \\
$\begin{array}{l}\text { - neurological and mental } \\
\text { diseases }\end{array}$ & 20 & 11.11 \\
$\begin{array}{l}\text { - digestive system diseases } \\
7 \text { - cancer }\end{array}$ & 4 & 2.22 \\
8 - renal disease & 15 & 8.33 \\
$\begin{array}{l}\text { - other diseases: visual dis- } \\
\text { turbances, infectious diseases, } \\
\text { dermatological diseases }\end{array}$ & 5 & 3.33 \\
\hline
\end{tabular}


patients, respectively, the OE-15 Therapeutic Education Expectations Scale, and a demographic survey that allowed us to collect demographic data and information concerning the subjects' health.

The Multidimensional Health Locus of Control Scale (MHLC) by Wallston, Wallston and DeVellis was designed following the main assumptions of the social learning theory (Wallston \& Wallston, 1978; Wallston et al., 1987; Juczyński, 2001). The scale covers three dimensions of the health locus of control:

1) internal I - control over one's own body depends on the individual;

2) influence of other persons (external) $\mathrm{P}$ - the individual's health results from actions of powerful others, especially the medical personnel;

3) chance (external) $\mathrm{C}$ - the individual's health results from chance, and chance determines health (Juczyński, 2001).

The Multidimensional Health Locus of Control Scale was several times subject to structural analyses that verified its coherence. The results demonstrated moderate homogeneity of the I and P scales, whereas the index obtained in the $\mathrm{C}$ scale increased with the age of the subjects, lower social status and the occurrence of diseases, the course of which is severe (Winefield, 1982).

The MHLC scale consists of 18 items, 6 for each dimension. The subject's task is to specify on the 6-point scale [ranging from 1 (I strongly disagree) to 6 (I strongly agree)] one's attitude towards the items included in the questionnaire. Results are calculated separately for each scale, and points obtained are added up; the results cannot be presented by means of one general index. The range of results obtained for each of the three scales covers the section between 6 and 36 points. The higher the result, the stronger is the belief of the individual about the influence of a given factor on their own health (Juczyński, 2001).

The reliability of the MHLC instrument determines the value of Cronbach's $\alpha$ coefficient of internal cohesion specified for each dimension of the I, P, and $\mathrm{C}$ scales, which in their Polish version fell within the .69-.72 range and were close to the coefficients in the original version. The accuracy of the Polish version of the MHLC instrument was evaluated on the basis of research conducted, the results of which demonstrated statistically significant correlations between: the dimension of inner control and self-efficacy $(r=.32)$, self-esteem $(r=.32)$ and health estimation $(r=.30)$ (Juczyński, 2001).

The OE-15 Therapeutic Education Expectations Scale by Andruszkiewicz and Basińska.

The instrument developed for researching expectations of education-related activities implemented by healthcare professionals is suitable for patients staying in hospital or at home. Questions concerning expectations as to the education system were divided into three categories: the first referred to expectations as to information on the disease and its treatment, the second addressed the way the disease affects various aspects of life, and finally the third concerned information on the disease prevention. The factor analysis corroborated the validity of distinguishing the three abovementioned factors. Additionally, respondents were also asked who, in their opinion, should take care of education and in what form, and what form would be relevant in their opinion for continuing education following hospital discharge (Andruszkiewicz \& Basińska, in press).

Relevant codes were assigned to answers given: no $=0$, probably no $=1$, probably yes $=2$ and yes $=3$. The mean value for the entire 15-item scale in the group under research was $M=41.33(S D=5.42)$, with the possible range between 0 and 60 , which indicates extensive differences as to expectations of education. Education expectations can be presented by means of one general index, and the higher score the research subjects get, the higher expectations they have as regards obtaining information.

Reliability for the entire 15-item scale expressed as Cronbach's $\alpha$ coefficient was .90. All the items are similar to one another in terms of cohesion $(\alpha$ when deleted from .89 to .90$)$. The research performed so far in the group of female cancer patients (.80), hypertensive patients (.92) and patients with other cardiovascular diseases (.82) shows good reliability parameters (Andruszkiewicz \& Basińska, in press). Reliability for factors separated in the group under research was: .88 for factor I - expectations as to information about the disease and its treatment; .76 for factor II - expectations as to explaining the influence of the disease on various aspects of life; and .88 for factor III - expectations as to information on the disease-related prevention.

Moreover, the group of 360 patients (cardiovascular diseases, diseases of the digestive tract and tuberculosis) underwent the examination with the application of the Patient Request Form and the Education Expectations Scale. The results obtained validated the accuracy of the scale developed (Andruszkiewicz \& Basińska, in print).

\section{RESEARCH ORGANISATION}

The first stage of the research concerned chronically ill patients, and the group inclusion criteria embraced a medical diagnosis of a chronic disease; duration of the disease could not be shorter than a year. Patients stayed at home during the research and were taken care of by either their GP or a specialist physician. In the next stage of the research the group was extended by healthy controls (comparison group). The inclusion criterion was the absence of any diagnosed chronic disease.
Chronically ill patients' expectations of therapeutic education 
The research was performed in line with principles stipulated in the Declaration of Helsinki. The consent for the research was obtained from the Bioethical Committee of the Collegium Medicum of the Nicolaus Copernicus University in Torun.

\section{RESULTS}

\section{EDUCATION EXPECTATIONS}

Małgorzata Anna Basińska, Anna Andruszkiewicz
The research subjects are of the opinion that disease-related education should be provided by a team of experts. Patients more frequently than healthy controls $\left(\chi^{2}=14.54, d f=1, p<.001\right)$ want this education to be provided by a doctor, and healthy controls want it to be provided by the team $\left(\chi^{2}=4.48, d f=1\right.$, $p=.030)$ (Table 3).

About $50 \%$ of the research subjects, both patients and healthy controls, think that disease-related education should be provided with a variety of methods. Healthy controls express such opinions significantly more frequently than patients $\left(\chi^{2}=4.16, d f=1, p=.040\right)$ (Table 4).

Following hospital discharge, patients would like to get a leaflet including all necessary information (Table 5). Healthy controls significantly more fre- quently $\left(\chi^{2}=5.05, d f=1, p=.020\right)$ than patients expected that after being discharged from hospital they would be able to find basic information obtained in the hospital on the website designed and developed specifically for patients.

As regards the form of obtaining information, patients would like to be informed, most frequently, during an individual talk, and healthy controls would prefer varied forms of education (Table 6).

No statistically significant differences were found between the research subjects regarding the increase in general expectations of education according to gender (Table 7) and health (Table 8). Yet, as far as the factors distinguished are concerned, male subjects and healthy controls were more interested in information on the influence of the disease on various aspects of life.

\section{HEALTH LOCUS OF CONTROL}

Statistically significant differences were observed between patients and healthy controls in all dimensions of beliefs about the health locus of control (Table 9). Patients less frequently have an internal locus of control and more frequently have an external locus of control, in other persons or in chance.

Table 3

Number of subjects according to their patient education views

\begin{tabular}{|c|c|c|c|c|c|c|c|c|}
\hline \multirow{3}{*}{$\begin{array}{l}\text { Who should deal with patient } \\
\text { education? }\end{array}$} & \multicolumn{4}{|c|}{ Patients } & \multicolumn{4}{|c|}{ Healthy controls } \\
\hline & \multicolumn{2}{|c|}{ yes } & \multicolumn{2}{|c|}{ no } & \multicolumn{2}{|c|}{ yes } & \multicolumn{2}{|c|}{ no } \\
\hline & $f$ & $\%$ & $f$ & $\%$ & $f$ & $\%$ & $f$ & $\%$ \\
\hline Physician & 42 & 24 & 133 & 76 & 7 & 6 & 102 & 94 \\
\hline Education nurse & 44 & 25 & 131 & 75 & 26 & 24 & 83 & 76 \\
\hline Psychologist & 10 & 6 & 165 & 94 & 7 & 6 & 102 & 94 \\
\hline Nutritionist & 7 & 4 & 168 & 96 & 3 & 3 & 106 & 97 \\
\hline Team of experts & 107 & 61 & 68 & 39 & 80 & 73 & 29 & 27 \\
\hline
\end{tabular}

Table 4

Number of subjects according to their patient education views

\begin{tabular}{|c|c|c|c|c|c|c|c|c|}
\hline \multirow{3}{*}{ The form of patient education? } & \multicolumn{4}{|c|}{ Patients } & \multicolumn{4}{|c|}{ Healthy controls } \\
\hline & \multicolumn{2}{|c|}{ yes } & \multicolumn{2}{|c|}{ no } & \multicolumn{2}{|c|}{ yes } & \multicolumn{2}{|c|}{ no } \\
\hline & $f$ & $\%$ & $f$ & $\%$ & $f$ & $\%$ & $f$ & $\%$ \\
\hline Leaflet & 24 & 14 & 151 & 86 & 8 & 7 & 101 & 93 \\
\hline Film & 44 & 25 & 131 & 75 & 4 & 4 & 105 & 96 \\
\hline Individual talk & 5 & 3 & 170 & 97 & 47 & 43 & 62 & 57 \\
\hline Group talk & 9 & 5 & 166 & 95 & 2 & 2 & 107 & 98 \\
\hline All methods & 73 & 42 & 102 & 58 & 59 & 54 & 50 & 46 \\
\hline
\end{tabular}


Table 5

Number of subjects according to their expectations concerning the possibility of finding necessary information following hospital discharge

\begin{tabular}{|c|c|c|c|c|c|c|c|c|}
\hline \multirow{3}{*}{$\begin{array}{l}\text { Following hospital discharge } \\
\text { I will be able to find information } \\
\text { obtained in the hospital }\end{array}$} & \multicolumn{4}{|c|}{ Patients } & \multicolumn{4}{|c|}{ Healthy controls } \\
\hline & \multicolumn{2}{|c|}{ yes } & \multicolumn{2}{|c|}{ no } & \multicolumn{2}{|c|}{ yes } & \multicolumn{2}{|c|}{ no } \\
\hline & $f$ & $\%$ & $f$ & $\%$ & $f$ & $\%$ & $f$ & $\%$ \\
\hline $\begin{array}{l}\text { In the leaflet prepared for } \\
\text { patients }\end{array}$ & 107 & 61 & 68 & 39 & 62 & 57 & 47 & 43 \\
\hline On the website & 54 & 31 & 121 & 69 & 48 & 44 & 61 & 56 \\
\hline $\begin{array}{l}\text { In meetings organised regularly } \\
\text { for patients }\end{array}$ & 23 & 13 & 152 & 87 & 12 & 11 & 89 & 97 \\
\hline No expectations & 15 & 9 & 160 & 91 & 6 & 5 & 103 & 95 \\
\hline
\end{tabular}

Chronically ill patients' expectations of therapeutic education

Table 6

Number of subjects according to their expectations concerning forms of education applied

\begin{tabular}{|c|c|c|c|c|c|c|c|c|}
\hline \multirow{3}{*}{ Forms of education applied } & \multicolumn{4}{|c|}{ Patients } & \multicolumn{4}{|c|}{ Healthy controls } \\
\hline & \multicolumn{2}{|c|}{ yes } & \multicolumn{2}{|c|}{ no } & \multicolumn{2}{|c|}{ yes } & \multicolumn{2}{|c|}{ no } \\
\hline & $f$ & $\%$ & $f$ & $\%$ & $f$ & $\%$ & $f$ & $\%$ \\
\hline Leaflet & 24 & 14 & 151 & 86 & 8 & 7 & 101 & 93 \\
\hline Film & 2 & 2 & 170 & 97 & 4 & 4 & 105 & 96 \\
\hline Individual talk & 93 & 53 & 82 & 47 & 47 & 43 & 62 & 57 \\
\hline Group talk & 9 & 5 & 166 & 95 & 2 & 2 & 107 & 98 \\
\hline All methods & 73 & 42 & 102 & 58 & 59 & 54 & 50 & 46 \\
\hline
\end{tabular}

Table 7

Significance of differences between means as regards education expectations between male and female research subjects

\begin{tabular}{lcccccc}
\hline Education expectations & \multicolumn{2}{l}{ Women $n=183$} & Men $n=100$ & $\begin{array}{c}\text { Statistical } \\
\text { test }\end{array}$ & $p$ \\
\cline { 2 - 5 } & $M$ & $S D$ & $M$ & $S D$ & & \\
\hline $\begin{array}{l}\text { I information on the disease and its } \\
\text { treatment }\end{array}$ & 13.81 & 2.14 & 14.06 & 2.07 & $t=-0.93$ & .351 \\
$\begin{array}{l}\text { II explanation of the influence of the } \\
\text { disease on various aspects of life }\end{array}$ & 7.52 & 2.11 & 8.10 & 1.70 & $z=-2.06$ & .040 \\
$\begin{array}{l}\text { III information on disease-related } \\
\text { prevention }\end{array}$ & 19.61 & 2.54 & 19.68 & 2.48 & $t=-0.22$ & .823 \\
\begin{tabular}{l} 
Education expectations in total \\
\hline
\end{tabular} & 40.95 & 5.69 & 41.84 & 4.86 & $t=-1.32$ & .187 \\
\hline
\end{tabular}

Note. $t$ - results of Student's $t$-test; $z$ - results of Mann-Whitney $U$ test

\section{THE RELATION BETWEEN BELIEFS ABOUT THE HEALTH LOCUS OF CONTROL AND EDUCATION EXPECTATIONS}

A statistically significant relation was observed between beliefs about the health locus of control and education expectations only in the group of healthy controls $(R=-.22, p=.022)$. Expectations of disease-related information and its treatment negatively correlate with external beliefs - in other persons. When healthy persons are convinced that health control is placed in other persons, then their expectations concerning the disease and its treatment are lower. Other dimensions of expectations of education and beliefs about the health locus of control in both groups - patients and healthy controls - were not statistically significant. 
Table 8

Significance of differences between means in relation to education expectations between research subjects: patients and healthy controls

\begin{tabular}{llccccc}
\hline Education expectations & \multicolumn{2}{c}{$\begin{array}{c}\text { Patients } \\
n=174\end{array}$} & $\begin{array}{c}\text { Healthy controls } \\
n=109\end{array}$ & $\begin{array}{c}\text { Statistical } \\
\text { test }\end{array}$ & $p$ \\
\cline { 2 - 5 } & $M$ & $S D$ & $M$ & $S D$ & \\
\hline $\begin{array}{l}\text { I information on the disease and its } \\
\text { treatment }\end{array}$ & 13.88 & 2.18 & 13.93 & 2.02 & $t=-0.18$ & .855 \\
$\begin{array}{l}\text { II explanation of the influence of the } \\
\text { disease on various aspects of life }\end{array}$ & 7.30 & 2.28 & 8.42 & 1.12 & $z=-3.53$ & .001 \\
$\begin{array}{l}\text { III information on disease-related prevention } \\
\text { Education expectations in total }\end{array}$ & 19.59 & 2.72 & 19.70 & 2.15 & $t=-0.36$ & .718 \\
\end{tabular}

Note. $t$ - results of Student's $t$-test; $z$ - results of Mann-Whitney $U$ test

Table 9

Descriptive statistics for beliefs about health locus of control and significance of differences between means between research subjects: patients and healthy controls

\begin{tabular}{|c|c|c|c|c|c|c|c|c|c|c|}
\hline \multirow{2}{*}{ LOC } & \multicolumn{4}{|c|}{ Patients $n=174$} & \multicolumn{4}{|c|}{ Healthy controls $n=109$} & \multirow{2}{*}{$\begin{array}{c}\text { Statistical } \\
\text { test }\end{array}$} & \multirow[t]{2}{*}{$p$} \\
\hline & $M$ & $S D$ & $\min$ & $\max$ & $M$ & $S D$ & $\min$ & $\max$ & & \\
\hline Internal & 24.91 & 4.89 & 12.00 & 36.00 & 26.50 & 4.38 & 14.00 & 36.00 & $t=-2.76$ & .006 \\
\hline Other persons & 24.55 & 5.37 & 11.00 & 36.00 & 19.31 & 5.18 & 7.00 & 30.00 & $z=8.05$ & $<.001$ \\
\hline Chance & 21.13 & 5.97 & 6.00 & 36.00 & 18.48 & 6.15 & 6.00 & 34.00 & $t=3.58$ & $<.001$ \\
\hline
\end{tabular}

Note. $t$ - results of Student's $t$-test; $z$ - results of Mann-Whitney $U$ test

In order to deepen the analyses on relations between education expectations and beliefs about the health locus of control, the research subjects were divided by means of the $k$-mean method into two clusters that had been indicated earlier by the agglomeration method. The first cluster included persons in whom all three types of belief about the health locus

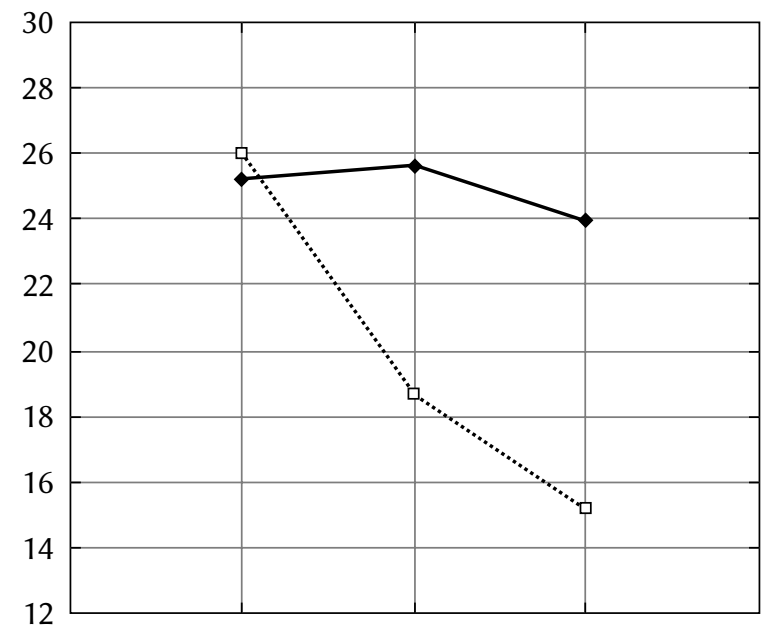

Internal Other people Chance

$\rightarrow$ Cluster I …… Cluster 2

Figure 1. Diagram of means for beliefs about the health locus of control for each cluster. of control were at a similar level, whereas the second group included persons with an internal health locus of control and low external beliefs (Figure 1).

Cluster 1, the representatives of which manifested similar intensity of all three types of beliefs about the health locus of control, included 158 persons (56.23\%), and Cluster 2, the representatives of which had significantly intense beliefs about an internal health locus of control, included 123 persons (43.77\%). The persons in the clusters significantly differed among themselves as to external beliefs about the health locus of control (in other persons $t=7.02, p<.001$ and in chance $t=3.24, p<.001)$ and as to beliefs about internal locus of control (internal $t=-2.13, p=.034$ ).

Cluster 1 included 155 patients (98.00\%) and $3(2.00 \%)$ healthy controls, $108(68.00 \%)$ women and $50(32.00 \%)$ men. In Cluster 2 healthy controls prevailed $(n=104,85.00 \%)$, and the number of patients ( $n=19,15.00 \%)$ and men was lower $(n=49,40.00 \%)$, whereas the number of women was higher $(n=74$, $60.00 \%)$. Persons in the clusters differed in age, too. The mean for Cluster 1 was 51.27 years $(S D=13.61)$ and was significantly higher than the mean for Cluster $2(M=39.19, S D=9.96, z=7.56, p<.001)$.

The next step was to verify whether the subjects differ in terms of education expectations with reference to the structure of beliefs about the health locus of control. It turned out that the subjects differ 
significantly in terms of education expectations with reference to the structure of beliefs about the health locus of control only as to the second factor, i.e., explanation of the influence of the disease on other aspects of life. Persons belonging to Cluster 2, where the internal health locus of control was dominant, significantly more often expected the influence of the disease on various aspects of life to be explained (Table 10).

\section{DISCUSSION}

A few decades ago, health education, being dependent on the biomedical paradigm that was predominant in medicine, was focusing on the disease, and the focus of interest was an individual isolated from the broadly understood human context of functioning (Słońska, 2001). Today, the individual is approached holistically, and their health problems are analysed in a wider context of various aspects of life. This is reflected in the human ecosystem model, i.e., the so-called Health Mandala developed by the Public Health Department in Toronto. The basic assumption of the model is to recognise the existence of complex relations between the human being and their environment. The primary role is played here by the new concept of the human, being far away from the dualism of Descartes where the focus is placed on the thoughts and feelings of the patient, and takes into account their relation with the general health condition.

The OE-15 scale for examining therapeutic education expectations, propounded in this paper, appeared to be a reliable instrument in the group under research. It allowed us to obtain a general result and partial results concerning education expectations that pertain to information on the disease and its treatment (I), explanation of the influence of the disease on various aspects of life (II), and information on disease-related prevention (III). The scale requires further research in order to verify the relations be- tween expectations of therapeutic education and personality features of patients as well as with situations resulting from the specificity of treatment; this effort was initiated in this paper.

Education expectations research has performed a substantial role in prevention, treatment and rehabilitation of chronic diseases (Loring, 1997; Marcolongo \& Bonadiman, 2004; National Board of Health Patient Education - a Health Technology Assessment Copenhagen, 2009); it also constitutes an integral part of taking care of patients (Boucher, Shafer, \& Chaffin, 2001; Marcolongo \& Bonadiman, 2004; National Board of Health Patient Education a Health Technology Assessment Copenhagen, 2009). Education is a particularly vital tool in the treatment of chronic diseases (Boucher et al., 2001; Marcolongo \& Bonadiman, 2004; National Board of Health Patient Education - a Health Technology Assessment Copenhagen, 2009; Lagger et al., 2010) as it complements and supports therapies (Kocur, 1998; National Board of Health Patient Education - a Health Technology Assessment Copenhagen, 2009). Moreover, it allows one to reduce treatment costs, and this factor has been increasingly important in modern healthcare systems (Assal, 1995; Glimer \& O'Concor, 1997; Tatoń \& Biernas, 2002).

The major objective of this research was to verify whether expectations patients have of therapeutic education differ according to gender and health, and whether these expectations demonstrate a relation with beliefs about the health locus of control. The analyses performed indicate that gender, health and beliefs about the health locus of control were related to expectations as to therapeutic education in the research subjects. Men, healthy controls and persons with an internal health locus of control have substantially higher expectations from education as regards obtaining information on the influence of the disease on such aspects of life as professional career, sexual life and inheritance of the disease by the children. The obtained results are different from those acquired previously, which seemed to suggest that women have
Chronically ill patients' expectations of therapeutic education

Table 10

Significance of differences between means in terms of education expectations between research subjects according to the structure of beliefs about the health locus of control

\begin{tabular}{|c|c|c|c|c|c|c|}
\hline \multirow[t]{2}{*}{ Education expectations } & \multicolumn{2}{|c|}{$\begin{array}{c}\text { Cluster } 1 \\
n=158\end{array}$} & \multicolumn{2}{|c|}{$\begin{array}{c}\text { Cluster } 2 \\
n=123\end{array}$} & \multirow[t]{2}{*}{$\begin{array}{l}\text { Statistical } \\
\text { test }\end{array}$} & \multirow[t]{2}{*}{$p$} \\
\hline & $M$ & $S D$ & $M$ & $S D$ & & \\
\hline I information on the disease and its treatment & 13.98 & 1.89 & 13.79 & 2.39 & $t=0.76$ & .451 \\
\hline $\begin{array}{l}\text { Il explanation of the influence of the disease } \\
\text { on various aspects of life }\end{array}$ & 7.35 & 2.27 & 8.20 & 1.44 & $z=-2.66$ & .008 \\
\hline III information on disease-related prevention & 19.66 & 2.59 & 19.56 & 2.43 & $t=0.34$ & .733 \\
\hline Education expectations in total & 40.99 & 5.57 & 41.55 & 5.23 & $t=-0.86$ & .392 \\
\hline
\end{tabular}

Note. $t$ - results of Student's $t$-test; $z$ - results of Mann-Whitney $U$ test 
Małgorzata Anna Basińska,

Anna Andruszkiewicz higher expectations of their physician (Zieniuk, 2009), particularly when it comes to psychological support (Juczyński, 2001; Glińska et al., 2013).

Health was also related to education expectations of the research subjects. The subject literature corroborates the postulate that both a disease and the stage of treatment contribute to the emergence of diversified expectations (Laskowka \& Tulińska, 2006; Zieniuk, 2009; Kapała, Chudziński, \& Hyrcza, 2008). It seems that the change of perspective that follows the onset of the disease substantially modifies human perception that is the foundation for understanding all the phenomena taking place in the surrounding environment. The cognitive structure that is related to imagination results in perceived sensual impressions being modified by expectations, needs, sensations and defensive mechanisms. The cognitive structure that is related to intelligence adjusts impressions recorded in our imagination by comparing them with existing knowledge and experience (Falkowski, 2004). Healthy controls have different experiences than patients - they think they might have similar education expectations. Moreover, the reasons for differences in education expectations between patients and healthy controls result from subjective perception of the world, owing to which the human adjusts to reality; this perception is controlled not only by those information items that access it but most of all through the way they are processed (Skarżyńska, 1981), and this depends also on health.

The research on various groups of chronically ill patients demonstrates a more frequent external health locus of control - in other persons or in circumstances such as chance or luck - whereas the internal health locus of control is at a similar level as it is in healthy controls. This trend was also observed in our research results. Does this structure of beliefs result, at least partly, from the disease? The answer to this question is difficult. Longitudinal studies have not been carried out; only comparison studies between various groups of patients have been performed. For instance, haemodialysis patients have a significantly higher level of external health locus of control (in other persons) than patients taking care of themselves on their own (Wallston \& Wallston, 1982). The degree of constraints that results from a given disease and the severity of its course are essential (Heszen \& Sęk, 2007; Czubalski, 1995). One may conclude that the disease to a certain extent enforces transferring - at least partly - health control to physicians (Basińska, 2009). The control perceived in a chronic disease must perceive the role of the physician as essential so as not to be illusory.

The question about the relation between beliefs concerning the health locus of control and therapeutic education expectations may be answered positively. Persons in whom the belief about the internal health locus of control is dominant have higher expectations pertaining to obtaining explanations on the influence of the disease on various aspects of their lives. Beliefs held by humans about their capability to take independent decisions, affect negative and harmful events, determine their own internal states and behaviours as well as influence their environment are referred to as control perception or perceived control (Wallston et al., 1987); this seems to form the basis for the emergence of expectations concerning explanation of the influence of the disease on various aspects of life. Only a person who has such beliefs wants to know more: in their view this information will be helpful in affecting their lives and probably in avoiding everything that may be adverse and harmful.

\section{CONCLUSIONS}

The OE-15 Therapeutic Education Expectations Scale is a reliable method in the group under research.

Gender, health and beliefs about locus of control are related to education expectations in the group under research.

The research on therapeutic education expectations is feasible and reasonable only in patients, since the research on healthy controls consists in studying their images and impressions that in a specific situation of disease occurrence may cease to be important.

\section{LIMITATIONS OF THE STUDY}

The work explores the issues that are considered to be important from the perspective of somatically ill patients in providing information about the disease, its course and complications. Readers can familiarize themselves with a scale that measures patients' expectations regarding the above issues. Since the research focuses on exploring expectations from education, the authors do not make a hypothesis, but focus on the research objectives. Besides, healthy subjects were not sampled to match the sick subjects in terms of age, sex and education. The objective was rather to assess whether expectations from education are of different nature in the sample of healthy individuals and sick ones. Further research is needed in order to analyse the problem in much greater detail.

\section{REFERENCES}

Abramczyk, A. (2010). Oczekiwania chorych na cukrzycę w zakresie edukacji w świetle badań ogólnopolskich [Expectations of diabetes patients within the scope of education in the light of nationwide research]. Problemy Pielegniarstwa, 18, 249-259.

Andruszkiewicz, A., \& Basińska, M. A. (in press). Skala oczekiwań od edukacji terapeutycznej osób 
chorych [The scale of expectations from the therapeutic education of patients]. Problemy Pielegniarstwa.

Assal, J. P. (1995). Social and cost implications of type II diabetes. Pharmaco Economics, 8, 86-97.

Astin, F., Closs, S. J., McLenachan, J., Hunter, S., \& Priestley, C. (2009) Primary angioplasty for heart attack: mismatch between expectations and reality? Journal of Advanced Nursing, 65, 72-83.

Basińska, M. A. (2005). Przygotowanie pacjenta do zabiegu - aspekty psychologiczne [Preparation patients for the surgery - psychological aspects]. Valetudinaria - Postępy Medycyny Klinicznej i Wojskowej, 10, 40-43.

Basińska, M. A. (2009). Funkcjonowanie psychologiczne pacjentów w wybranych chorobach endokrynologicznych. Uwarunkowania somatyczne i osobowościowe [Psychological functioning of patients in selected endocrine diseases. Somatic and personality detrminants]. Bydgoszcz: Wydawnictwo Uniwersytetu Kazimierza Wielkiego.

Basińska, M. A., Maćkowska, P., \& Listwan, A. (2011). Przekonania o umiejscowieniu kontroli zdrowia chorych na cukrzycę typu 1 a zachowania zdrowotne [Health locus of control in patients with type 1 diabetes and health behaviours]. Diabetologia Praktyczna, 12, 151-159.

Beier, M. E., \& Ackerman, P. L. (2003). Determinants of health knowledge: an investigation of age, gender, abilities, personality, and interests. Journal of Personality and Social Psychology, 84, 439-448.

Bishop, G. D. (2000). Psychologia zdrowia [Health Psychology]. Wrocław: Wydawnictwo Astrum.

Boucher, J. L., Shafer, K. J., \& Chaffin, J. A. (2001). Weight loss, diets, and supplements: does anything work? Diabetes Spectrum, 14, 169-175.

Briggs, L. A., Kirchhoff, K. T., Hammes, B. J., Song, M. K., \& Colvin, E. R. (2004). Patient-centered advance care planning in special patient populations: a pilot study. Journal of Profesional Nursing, 20, 47-58.

Czubalski, K. (1995). Wpływ choroby na stan psychiczny i zachowanie człowieka chorego [The impact of the disease on the mental state and behavior of a sick person]. Sztuka Leczenia, 1, 53-59.

Danish Centre for Health Technology Assessment, National Board of Health Patient Education a Health Technology Assessment Copenhagen: National Board of Health, Monitoring \& Health Technology Assessment (2009). Health Technology Assessment 11.

Deccache, A., \& Aujoulat, A. (2001). An European perspective: common developments, differences and challenges in patient education. Patient Education and Counseling, 44, 7-14.

Dreeben-Irimia, O. (2009). Patient education in rehabilitation. Burllington: Jones \& Bartlett Learning.
Falkowski, A. (2004). Psychologiczne podstawy marketingu [Psychological basics of marketing]. In T. Tyszka (ed.), Psychologia ekonomiczna [The economic Psychology] (pp. 368-401). Gdańsk: GWP.

Fryc-Martyńska, J. (1989). Psychologiczne następstwa wytworzenia odbytu brzusznego oraz znaczenie sposobu informowania chorych i ich rodzin [Psychological produce abdominal anus and the importance of how to inform patients and their families]. Polski Tygodnik Lekarski, 20, 469-471.

Gambling, T., \& Long, A. F. (2010). The realisation of patient-centred care during a 3-year proactive telephone counselling self-care intervention for diabetes. Patient Education and Counselling, 80, 219-226.

Glimer, T. P., \& O'Concor, P. J. (1997). The cost to held plans of poor glycemic control. Diabetes Care, 20, 1847-1853.

Glińska, J., Malesza, M., Lewandowska, M., Miller, R., Dziki, Ł., \& Dziki, A. (2013). Oczekiwania emocjonalne oraz kontrola emocji pacjentów z rakiem jelita grubego po wyłonieniu stomii jelitowej [Emotional expectations and emotional control of colorectal cancer patients after colostomy]. Pielęgniarstwo Chirurgiczne i Angiologiczne, 3, 84-91.

Heszen, I., \& Sęk, H. (2007). Psychologia zdrowia [Health Psychology]. Warszawa: Wydawnictwo Naukowe PWN.

Halsted, H. (2004). Chronic disease - the need for a new clinical education. Journal of the American Medical Association, 292, 1057-1059.

Hoglund, A. T., Winblad, U., Arnetz, B., \& Arnetz, J. E. (2010). Patient participation during hospitalization for myocardial infarction: perceptions among patients and personnel. Scandinavian Journal of Caring Sciences, 24, 482-490.

Juczyński, Z. (2001). Narzędzia pomiaru w promocji i psychologii zdrowia [Measurement tools in the promotion and health psychology]. Warszawa: Pracownia Testów Psychologicznych Polskiego Towarzystwa Psychologicznego.

Kapała, W., Chudziński, S., \& Hyrcza, S. (2008). Oczekiwania pacjentów hospitalizowanych na oddziałach zabiegowych wobec personelu pielęgniarskiego [Expectations of patients hospitalized in surgical wards to the nursing staff]. Pieleggniarstwo Chirurgiczne i Angiologiczne, 1, 12-18.

Kocur, J. (1998). Znaczenie edukacji terapeutycznej u pacjentów przewlekle chorych [The importance of therapeutic education for patients with chronic diseases]. Sztuka Leczenia, 4, 81-84.

Kubica, A. B. (2012). Edukacja zdrowotna na tle wybranych czynników a skuteczność terapii antyagregacyjnej [Health education on the background of selected factors on the effectiveness of anti-platelet therapy]. Toruń: Wydawnictwo Naukowe UMK.

Lagger, G., Pataky, Z., \& Golay, A. (2010). Efficacy of therapeutic patient education in chronic diseases
Chronically ill patients, expectations of therapeutic education 
Małgorzata Anna Basińska, Anna Andruszkiewicz and obesity. Patient Education and Counseling, 79, 283-286.

Laskowka, E., \& Tulińska, M. (2006). Jakość relacji lekarz-pacjent i jej wpływ na proces zdrowienia [The quality of the doctor-patient relationship and its effect on the healing process]. Neuroskop, $8,163-166$.

Levin-Zamair, D., \& Peterburg, Y. (2001). Health literacy in health systems: perspectives on patient self-management in Israel. Health Promotion International, 1, 87-94.

Lorgin, K. (2001). Patient education. A practical approach. Sage Publications, Thousand, Oaks, 12-15.

Loring, W. C. (1997). Environmental health education: a different orientation. International Journal of Health Education, 20, 51-56.

Marcolongo, R., \& Bonadiman, L. (2004). Therapeutic patient education in Italy: A critical outline. International Review of Asthma, 6, 52-61.

Masters, K. S., \& Wallston, K. A. (2005). Canonical correlation reveals important relations between health locus of control, coping, affect and values. Journal of Health Psychology, 10, 719-731.

McKinley, R. K., \& Roberts, C. (2001). Patients satisfaction with out of hours primary medical care. Quality in Health Care, 10, 23-28.

Rachmani, R., Slavachevski, I., Berla, M., Frommer-Shapira, R., \& Ravid, M. (2005). Treatment of high-risk patients with diabetes: motivation and teaching intervention: a randomized, prospective 8-year follow-up study. Journal of the American Society of Nephrology, 16 (Suppl. 1), 22-26.

Rao, J. K., Weinberger, M., \& Kroenke, K. (2000). Visitspecific expectations and patient-centered outcomes. Archives Family Medicine, 9, 1148-1155.

Rotter, J. B. (1990). Poczucie wewnętrznej versus zewnętrznej kontroli wzmocnień [A sense of internal versus external control of reinforcements]. Nowiny Psychologiczne, 5-6, 59-70.

Sawicki, P. T., Mühlhauser, I., Didjurgeit, U., Baumgartner, A., Bender, R., \& Berger, M. (1995). Intensified antihypertensive therapy is associated with improved survival in type 1 diabetic patients with nephropathy. Journal of Hypertension, 13, 933-938.

Skarżyńska, K. (1981). Spostrzeganie ludzi [The perception of people]. Warszawa: Wydawnictwo Naukowe PWN.

Słońska, Z. (2001). Współczesna wizja edukacji zdrowotnej a promocja zdrowia [Contemporary vision of health education and health promotion]. In B. Woynarowska \& M. Kapica (eds.), Teoretyczne podstawy edukacji zdrowotnej. Stan i oczekiwania [Theoretical foundations of health education. Status and expectations]. Warszawa: KOWEZ.

Tatoń, J., \& Biernas, M. (2002). Pedagogika zdrowotna w cukrzycy [Health education in diabetes]. Medycyna Metaboliczna, 3, 25-33.
Tongue, J. R., Epps, H. R., \& Forese, L. L. (2005). Communication skills for patient-centered care. Journal of Bone \& Join Surgery, 87, 3, 652-658.

Vandervoort, D. J., Luis, P. K., \& Hamilton, S. E. (1997). Same correlates of health locus of control among multicultural individuals. Current Psychology: Developmental, Learning, Personality, Social, 16, 167-178.

Visser, S., Deccache, A., \& Bensing, J. (2001). Patient education in Europe: united differences. Patient Education and Counseling, 44, 1-5.

Wallston, B. S., \& Wallston, K. A. (1978). Locus of control and health: A review of the literature. Health Education Monographs, 6, 107-117.

Wallston, K. A., \& Wallston, B. S. (1982). Who is responsible for your health: The construct of health locus of control. In G. Sanders \& J. Suls (eds.), Social Psychology of Health and Illness (pp. 65-95). Hillsdale, N.J.: Lawrence Erlbaum \& Associates.

Wallston, K. A., Wallston, B. S., \& DeVellis, R. (1978). Development of the multidimensional health locus of control (MHLC) scales. Health Education Monographs, 6, 160-170.

Wallston, K. A., Wallston, B. S., Smith, S., \& Dobbins, C. (1987). Perceived control and health. Current Psychological Research and Reviews, 6, 5-25.

Wallston, K. A. (2005). The validity of the multidimensional health locus of control scales. Journal of Health Psychology, 10, 623-631.

West, E., Barron, D. N., \& Reeves, R. (2005). Overcoming the barriers to patient-centered care: time, tools and training. Journal of Clinical Nursing, 14, 435-443.

WHO Regional Office for Europa. (1998). Therapeutic patient education. Continuing programmers for health care providers in the field of prevention of chronicle diseases. Rapport of a WHO working group, Copenhagen.

Williams, S., Weinman, J., Dale, J., \& Newman, S. (1995). Patient expectations: What do primary care patients want from the GP and how far does meeting expectations affect patient satisfaction? Family Practice, 12, 193-201.

Williams, S. A. (1998). Quality and care, patient's perceptions. Journal of Nursing Care Quality, 12, 18-25.

Winefield, H. R. (1982). Reliability and validity of the Health Locus of Control Scale. Journal of Personality Assessment, 46, 614-619.

Zieniuk, A. M. (2009). Oczekiwania pacjenta onkologicznego wobec personelu medycznego [Expectations of oncological patients to medical staff]. Psychoonkologia, 1-2, 17-27. 